\title{
NOTE
}

\section{Synthesis of Optically Active Polyamines Based on Chiral 1-Cyclohexylethylamine Derivatives}

\author{
By Ataru KOBAYASHI, ${ }^{1}$ Gen-ichi KONISHI, ${ }^{1, *}$ and Kentaro SHIRAKI ${ }^{2}$
}

KEY WORDS: Optically Active Polymer / Polyamine / Polycondensation / 1-Cyclohexylethylamine / 1-Phenylethyamine / Circular Dichromism /

Recently, the precise control of macromolecular architectures has attracted considerable attention. Optically active polymers $^{1}$ often play important roles as key building blocks for well-defined polymers having specific higher-ordered structures. These polymers, therefore, have considerable potential for applications in the development of novel materials. In particular, chiral chromatography columns ${ }^{2}$ and gas permselective membranes ${ }^{3}$ based on these polymers are of considerable industrial importance. A variety of artificial optically active polymers, excluding bio-related polymers, such as polymethacrylate, ${ }^{4}$ polyacrylamide,${ }^{5}$ polyisocyanate,${ }^{6}$ polyacetylene, ${ }^{7}$ polysilane, ${ }^{8}$ etc., have attracted considerable attention in this regard. It is very important to extend the scope of synthetic approaches to optically active polymers for the development of novel materials in the future. From a synthetic viewpoint, chiral monomer polymerization is a usuful process because of the wide applicability of monomer, apart from both asymmetric polymerization of achiral or prochiral monomers and enantioselective polymerization of a racemic monomer. ${ }^{9}$ In this paper, we report on new optically active polymers having chiral auxiliary in the side chain prepared by the polycondensation of chiral 1-cyclohexylamine or 1-phenylethylamine with $p$-xylylene dibromide. The nitrogen atoms in the polymer backbone are expected to initiate the formation of a higherordered structure via inter- or intramolecular interaction and a ligand for molecular recognition. ${ }^{10}$

\section{EXPERIMENTAL}

\section{General}

Unless otherwise noted, all reagents and chemicals were used without further purification. $p$-Xylylene dibromide, benzylbromide, 1-cyclohexcylethylamines, and 1-phenylethylamines were obtained from TCI. 2,6-Dimethylnaphthalene and 2-bromomethylnaphthalene were obtained from Wako Pure Chem and Aldrich, respectively. All the ${ }^{1} \mathrm{H}$ NMR spectra (in $\mathrm{CDCl}_{3}-d$ ) and the ${ }^{13} \mathrm{C} \mathrm{NMR}$ spectra (in $\mathrm{CDCl}_{3}-d$ ) were recorded by a $400 \mathrm{MHz}$ JEOL LNM-EX400 instrument with tetramethylsilane (TMS) as the internal standard. The FT-IR spectra were recorded using a JASCO FT-IR 460 plus spectrometer. Gel permeation chromatography (GPC) was carried out by a JASCO UV-2070 detector and a JASCO RI2031 detector (TOSOH TSKgel $\mathrm{G} 3000 \mathrm{H}_{\mathrm{XL}}$ or $\mathrm{G} 4000 \mathrm{H}_{\mathrm{XL}}$ column) using tetrahydrofuran (THF) as the eluent after calibration with polystyrene standards. The solution property of the polymer in a diluted THF solution was examined by a SEC-VISC-RALLS system (Viscotek). Thermogravimetric analysis (TGA) was performed using a SII TG/DTA 6200 machine (SEIKO Instrument Inc.) with a heating rate of 10 ${ }^{\circ} \mathrm{C} / \mathrm{min}$ under a nitrogen atmosphere. Differential scanning calorimetry (DSC) was carried out on a SII DSC 6220 at a heating rate of $5{ }^{\circ} \mathrm{C} / \mathrm{min}$ under a nitrogen atmosphere. $\mathrm{CD}$ spectra were taken on a JASCO J-820 spectropolarimeter. Specific optical rotations were measured on a JASCO DIP1000 digital polarimeter in a $10 \mathrm{~cm}$ cuvette.

\section{General Procedure of Optically Active Polymer (1)}

Potassium carbonate $(10 \mathrm{mmol})$ was added to a solution of p-xylylene dibromide ( $2 \mathrm{mmol}),(\mathrm{R})-(-)-1$-cyclohexcylethylamine $(2 \mathrm{mmol})$, and acetonitrile/o-dichlorobenzene $(2 / 2 \mathrm{~mL})$ at room temperature. After stirring for $20 \mathrm{~h}$ at $90^{\circ} \mathrm{C},(\mathrm{R})-(-)-1-$ cyclohexcylethylamine $(2 \mathrm{mmol})$ was added to the resulting solution and stirred for $3 \mathrm{~h}$ at $90{ }^{\circ} \mathrm{C}$. After filtration and removal of solvent, the obtained residue was dissolved into minimum volume chloroform, and reprecipitated in methanol. The THF solution of the obtained product and benzyl bromide $(2 \mathrm{mmol})$ in the presence of potassium carbonate $(10 \mathrm{mmol})$ was refluxed for $3 \mathrm{~h}$. The resulting solution was filtered off to remove salt and then concentrated under reduced pressure. The obtained residue was dissolved into minimum volume chloroform, and reprecipitated in methanol. The obtained precipitate was dried in vacuo to give the optically active polymer $\mathbf{1}$.

Polymer 1(R). From (R)-(-)-1-cyclohexcylethylamine (0.254 $\mathrm{g}, 2 \mathrm{mmol}), p$-xylylene dibromide $(0.527 \mathrm{~g}, 2 \mathrm{mmol})$, Yield $51 \%$; $M_{\mathrm{n}}=7600, M_{\mathrm{w}}=17000, M_{\mathrm{w}} / M_{\mathrm{n}}=2.2 . ;{ }^{1} \mathrm{H} \mathrm{NMR}$ $\left(\mathrm{CDCl}_{3}, 400 \mathrm{MHz}, \mathrm{ppm}\right) \delta$ 7.54-7.27 (4H, Ph- $\left.\underline{\mathrm{H}}\right), 3.85-3.02$

\footnotetext{
${ }^{1}$ Department of Organic \& Polymeric Materials, Graduate School of Science \& Engineering, Tokyo Institute of Technology, 2-12-1-H-134, Ookayama, Meguro-ku, Tokyo 152-8552, Japan

${ }^{2}$ Institute for Applied Physics, University of Tsukuba, 1-1-1 Tennodai, Tsukuba 305-8573, Japan

*To whom correspondence should be addressed (Tel: +81-3-5734-2321, Fax: +81-3-5734-2888, E-mail: konishi.g.aa@m.titech.ac.jp).
} 


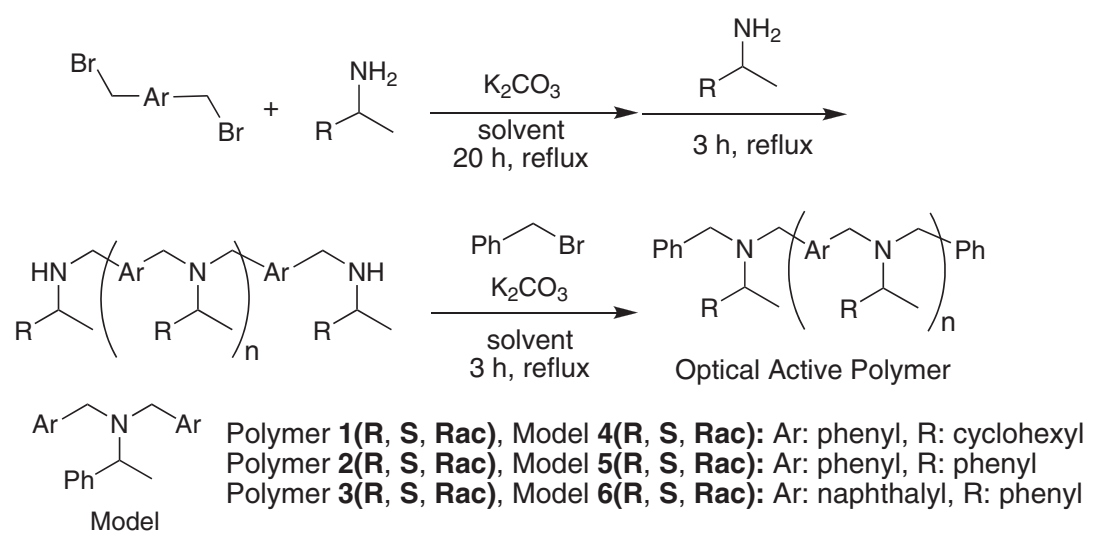

Scheme 1. Synthesis of optically active polyamines and model compounds.

(4H, Ph-C $\left.\underline{\mathrm{H}}_{2}-\mathrm{N}\right) 2.42-2.12,1.92-0.50\left(15 \mathrm{H}, \mathrm{C}_{6} \underline{\mathrm{H}}_{11}-\mathrm{CH}\left(\mathrm{CH}_{3}\right)-\right.$ $\mathrm{N})$; ${ }^{13} \mathrm{C} \mathrm{NMR}\left(\mathrm{CDCl}_{3}, 100 \mathrm{MHz}, \mathrm{ppm}\right) \delta 139.0,128.5,57.1$, 53.4, 41.2, 30.8, 30.7, 26.6, 26.5, 26.4.; IR $\left(\mathrm{NaCl}, \mathrm{cm}^{-1}\right)$ : $v=2920,2850,2810,1510,1450,1370,1140$.

Polymer 1(S). From (S)-(+)-1-cyclohexcylethylamine $(0.257$ $\mathrm{g}, 2 \mathrm{mmol}), p$-xylylene dibromide $(0.534 \mathrm{~g}, 2 \mathrm{mmol})$, Yield $59 \%$.; $M_{\mathrm{n}}=6800, \quad M_{\mathrm{w}}=13000, M_{\mathrm{w}} / M_{\mathrm{n}}=2.0 . ;{ }^{1} \mathrm{H} \mathrm{NMR}$ $\left(\mathrm{CDCl}_{3}, 400 \mathrm{MHz}, \mathrm{ppm}\right) \delta$ 7.43-7.10 (4H, Ph- $\left.\underline{\mathrm{H}}\right), 3.83-3.08$ (4H, Ph-C $\left.\underline{H}_{2}-\mathrm{N}\right) 2.40-2.19,1.81-0.52\left(15 \mathrm{H}, \mathrm{C}_{6} \underline{\mathrm{H}}_{11}-\mathrm{CH}\left(\mathrm{CH}_{3}\right)-\right.$ $\mathrm{N})$; ${ }^{13} \mathrm{C} \mathrm{NMR}\left(\mathrm{CDCl}_{3}, 100 \mathrm{MHz}, \mathrm{ppm}\right) \delta 139.0,128.5,57.1$, 53.3, 41.1, 30.8, 30.7, 26.6, 26.5, 26.3, 9.20.; IR $\left(\mathrm{NaCl}, \mathrm{cm}^{-1}\right)$ : $v=2920,2850,2810,1510,1450,1370,1140$.

Polymer 1(Rac). From (DL)-1-cyclohexcylethylamine $(0.255$ $\mathrm{g}, 2 \mathrm{mmol}), p$-xylylene dibromide $(0.530 \mathrm{~g}, 2 \mathrm{mmol})$, Yield $58 \%$; $M_{\mathrm{n}}=9400, \quad M_{\mathrm{w}}=18000, \quad M_{\mathrm{w}} / M_{\mathrm{n}}=1.9 . ;{ }^{1} \mathrm{H}$ NMR $\left(\mathrm{CDCl}_{3}, 400 \mathrm{MHz}, \mathrm{ppm}\right) \delta$ 7.39-7.20 (4H, Ph- $\left.\underline{\mathrm{H}}\right), 3.79-3.17$ (4H, Ph-C $\left.\underline{H}_{2}-\mathrm{N}\right) 2.40-2.20,1.76-0.58\left(15 \mathrm{H}, \mathrm{C}_{6} \underline{\mathrm{H}}_{11}-\mathrm{C} \underline{\mathrm{H}}\left(\mathrm{CH}_{3}\right)-\right.$ $\mathrm{N})$.; ${ }^{13} \mathrm{C} \mathrm{NMR}\left(\mathrm{CDCl}_{3}, 100 \mathrm{MHz}, \mathrm{ppm}\right) \delta 139.0,128.5,57.1$, 53.3, 41.1, 30.9, 30.7, 26.6, 26.5, 26.4, 9.10.; IR $\left(\mathrm{NaCl}, \mathrm{cm}^{-1}\right)$ : $v=2920,2850,2810,1510,1450,1370,1140$.

\section{General Procedure of Model Compound (4)}

Potassium carbonate $(50 \mathrm{mmol})$ was added to a solution of benzyl bromide (4 mmol), (R)-(-)-1-cyclohexcylethylamine $(2 \mathrm{mmol})$ and acetonitrile $(12 \mathrm{~mL})$ at room temperature. After refluxing for several hours, the mixture was filtred off to remove salt and then the resulting solution was concentrated under reduced pressure. The obtained residue was dissolved into chloroform $(10 \mathrm{~mL})$ and washed with water $(50 \mathrm{~mL} \times 3)$ to afford the model compound 4.

Model Compound 4(R). From (R)-(-)-1-cyclohexcylethylamine $(0.24 \mathrm{~g}, 1.8 \mathrm{mmol})$, benzylbromide $(0.67 \mathrm{~g}, 3.9 \mathrm{mmol})$, Yield 80\%.; ${ }^{1} \mathrm{H}$ NMR $\left(\mathrm{CDCl}_{3}, 400 \mathrm{MHz}, \mathrm{ppm}\right) \delta 7.39-7.19(\mathrm{~m}$, $10 \mathrm{H}), 3.77,3.31(\mathrm{dd}, J=13.9,13.9 \mathrm{~Hz}, 4 \mathrm{H}), 2.39-2.28(\mathrm{~m}$, $2 \mathrm{H}), 1.67-1.54(\mathrm{~m}, 4 \mathrm{H}), 1.23-1.02(\mathrm{~m}, 3 \mathrm{H}), 0.972(\mathrm{~d}, J=$ $6.6 \mathrm{~Hz}, 3 \mathrm{H}), 0.78-0.66(\mathrm{~m}, 2 \mathrm{H})$; ${ }^{13} \mathrm{C} \mathrm{NMR}\left(\mathrm{CDCl}_{3}, 100 \mathrm{MHz}\right.$, ppm) $\delta 140.7,128.7,128.0,126.5,57.4,53.6,41.2,30.9,30.7$, 26.6, 26.5, 26.4, 9.20.; IR $\left(\mathrm{NaCl}, \mathrm{cm}^{-1}\right) v=3030,2920,2850$, 1490, 1450, 1380, 1140.

Model Compound 4(S). From (S)-(+)-1-cyclohexcylethyl- amine $(0.26 \mathrm{~g}, 2 \mathrm{mmol})$, benzylbromide $(0.69 \mathrm{~g}, 4.1 \mathrm{mmol})$, Yield $87 \%$; ${ }^{1} \mathrm{H}$ NMR $\left(\mathrm{CDCl}_{3}, 400 \mathrm{MHz}, \mathrm{ppm}\right) \delta 7.39-7.19(\mathrm{~m}$, $10 \mathrm{H}), 3.77,3.31(\mathrm{dd}, J=13.9,13.9 \mathrm{~Hz}, 4 \mathrm{H}), 2.38-2.27(\mathrm{~m}$, $2 \mathrm{H}), 1.67-1.55(\mathrm{~m}, 4 \mathrm{H}), 1.23-1.02(\mathrm{~m}, 3 \mathrm{H}), 0.972(\mathrm{~d}, J=$ $6.6 \mathrm{~Hz}, 3 \mathrm{H}), 0.78-0.66(\mathrm{~m}, 2 \mathrm{H}) . ;{ }^{13} \mathrm{C} \mathrm{NMR}\left(\mathrm{CDCl}_{3}, 100 \mathrm{MHz}\right.$, ppm) $\delta 140.7,128.7,128.0,126.5,57.4,53.6,41.2,30.9,30.7$, 26.6, 26.5, 26.4, 9.20; IR $\left(\mathrm{NaCl}, \mathrm{cm}^{-1}\right) v=3030,2920,2850$, 1490, 1450, 1380, 1140.

Model Compound 4(Rac). From (DL)-1-cyclohexcylethylamine $(0.26 \mathrm{~g}, 2 \mathrm{mmol})$, benzylbromide $(0.69 \mathrm{~g}, 4.1 \mathrm{mmol})$, Yield 92\%; ${ }^{1} \mathrm{H}$ NMR $\left(\mathrm{CDCl}_{3}, 400 \mathrm{MHz}, \mathrm{ppm}\right) \delta 7.39-7.19$ (m, 10H), 3.77, $3.31(\mathrm{dd}, J=13.9,13.9 \mathrm{~Hz}, 4 \mathrm{H}), 2.39-2.28(\mathrm{~m}$, $2 \mathrm{H}), 1.67-1.57(\mathrm{~m}, 4 \mathrm{H}), 1.22-1.02(\mathrm{~m}, 3 \mathrm{H}), 0.972(\mathrm{~d}, J=$ $6.6 \mathrm{~Hz}, 3 \mathrm{H}), 0.78-0.66(\mathrm{~m}, 2 \mathrm{H}) . ;{ }^{13} \mathrm{C} \mathrm{NMR}\left(\mathrm{CDCl}_{3}, 100 \mathrm{MHz}\right.$, ppm) $\delta 140.7,128.7,128.0,126.5,57.4,53.6,41.2,30.9,30.7$, 26.6, 26.5, 26.4, 9.20; IR $\left(\mathrm{NaCl}, \mathrm{cm}^{-1}\right) v=3030,2920,2850$, 1490, 1450, 1380, 1140 .

\section{RESULTS AND DISCUSSION}

The typical procedure for the polymerization of chiral amines and dibromides is as follows (Scheme 1): An acetonitrile/o-dichlorobenzene (1/1) mixed solution containing an equimolar amount of $p$-xylylene dibromide and (R)-(-)-1cyclohexylethylamine was vigorously stirred and heated in the presence of $\mathrm{K}_{2} \mathrm{CO}_{3}$, and then, an excess amount of chiral amine was added to the solution. The terminal amine group was endcapped using an excess amount of benzyl bromide to yield a crude material. Further purification was carried out by reprecipitation in a methanol/acetone mixture. The optically active polymer $1 \mathbf{R}$ was obtained as a colorless precipitate. A similar polymerization procedure using other chiral and racemic amines afforded the corresponding polymers $1(\mathbf{S}$ and $\mathbf{R a c}), \mathbf{2}(\mathbf{R}$, $\mathbf{S}$, and $\mathbf{R a c})$, and $\mathbf{3}$ (R, S, and Rac). The obtained polymers had low solubility in acetone and acetonitrile, while they had good solubility in tetrahydrofuran (THF) and chloroform. Model compounds of each polymer were also prepared (Scheme 1).

The polymerization results are summarized in Table I. The yields of the polymers were $46 \%-79 \%$, while their molecular weights $M_{\mathrm{n}}$ found to be $5200-20000$ by GPC (eluent: THF; 
Table I. Properties of optically active polymers

\begin{tabular}{|c|c|c|c|c|c|c|c|c|c|c|c|}
\hline \multirow{3}{*}{ Entry } & \multirow{3}{*}{ Product } & \multirow{3}{*}{ Yield/\% } & \multicolumn{5}{|c|}{ Molecular Weight } & \multirow{3}{*}{$T_{\mathrm{g}} /{ }^{\circ} \mathrm{C}$} & \multirow{3}{*}{$T_{\mathrm{d} 10} /{ }^{\circ} \mathrm{C}$} & \multirow{2}{*}{\multicolumn{2}{|c|}{$[\alpha]_{D}^{20 c)}$}} \\
\hline & & & \multicolumn{2}{|c|}{ GPC $\left.^{a}\right)$} & \multicolumn{3}{|c|}{ LS $\left.^{b}\right)$} & & & & \\
\hline & & & $M_{\mathrm{n}}$ & PDI & $M_{\mathrm{w}}$ & PDI & a & & & Model & Polymer \\
\hline 1 & 1(R) & 51 & 7600 & 2.2 & 17000 & 1.6 & 0.68 & 82 & 296 & -21.8 & 7.08 \\
\hline 2 & $1(S)$ & 59 & 6800 & 2.0 & 14000 & 1.3 & 0.66 & 90 & 306 & 21.6 & -6.44 \\
\hline 3 & 1(Rac) & 58 & 9400 & 1.9 & 18000 & 1.3 & 0.68 & 93 & 301 & -0.06 & -0.07 \\
\hline 4 & $2(R)$ & 46 & 8600 & 2.1 & 21000 & 1.6 & 0.64 & 80 & 338 & 98.9 & 199 \\
\hline 5 & $2(S)$ & 68 & 18000 & 1.6 & 27000 & 1.2 & 0.72 & 81 & 309 & -98.0 & -207 \\
\hline 6 & 2(Rac) & 79 & 20000 & 1.5 & 34000 & 1.2 & 0.73 & 78 & 312 & -0.442 & -3.55 \\
\hline 7 & 3(R) & 54 & 6000 & 2.1 & 16000 & 1.1 & 0.63 & 108 & 339 & 150 & 303 \\
\hline 8 & $3(S)$ & 52 & 5800 & 2.2 & 16000 & 1.2 & 0.65 & 109 & 335 & -208 & -293 \\
\hline 9 & 3(Rac) & 62 & 5200 & 2.2 & 13000 & 1.1 & 0.64 & 106 & 312 & -3.46 & -3.41 \\
\hline
\end{tabular}

a) eluent: THF; polystyrene standards. b) Light Scattering (THF). c) Specific Rotation (THF, $20^{\circ} \mathrm{C}, \mathrm{c} 0.010$ for $\mathbf{6 ( R )}, \mathbf{6 ( S )}, \mathbf{6 ( R a c )}$ and c 0.10 for the others).

polystyrene standards) in each case. The absolute molecular weight $\left(M_{\mathrm{w}}\right)$ and solution properties were estimated using a SEC-VISC-RALLS system (Viscotek) with an online viscometer (VISC) and a right-angle laser light scattering (RALLS) detector in a diluted THF solution. The polymers were estimated to have $M_{\mathrm{w}}$ values of 13000-34000, and they exhibited a moderate Mark-Houwink-Sakurada $a$-value of $c a$. 0.63-0.73, suggesting that they have a random coil in a solution state, as expected. The thermal properties of the polymers were evaluated by DSC and TGA. The polymers were observed to have a glass transition temperature $\left(T_{\mathrm{g}}\right)$ ranging between $78-109^{\circ} \mathrm{C}$, and they were confirmed to have moderate thermal stability $\left(T_{\mathrm{d} 10}=296-339^{\circ} \mathrm{C}\right)$. In each case, no well-defined difference was observed among the $\mathbf{R}, \mathbf{S}$, and Rac polymers. The structures of the polymers were determined from their ${ }^{1} \mathrm{H}$ NMR, ${ }^{13} \mathrm{C}$ NMR, and FT-IR spectra; the FT-IR spectra indicated that none of the quaternary amines were contaminated. Therefore, the obtained polymers had a linear structure (supporting information Figure S1).

An inspection of the specific rotation data of the optically active polymers (Table I), particularly the rotation values, indicated that in a solution, the polymers take on some higherorder or regular structures that differ from those of the corresponding model compounds. In other words, a comparison of the polymers and model compounds revealed that the specific rotation was inverted from a negative value to a positive value in $\mathbf{1}(\mathbf{R}, \mathbf{S})$, and the specific rotation was approximately twice as high in $\mathbf{2}(\mathbf{R}, \mathbf{S})$ and $\mathbf{3}(\mathbf{R}, \mathbf{S}) .^{11}$

Meanwhile, the Cotton effect was observed in the CD spectra of the $\mathbf{R}$ and $\mathbf{S}$ optically active polymers. The $\mathbf{R}$ and $\mathbf{S}$ polymers were clearly observed to exhibit opposite Cotton effects; however, a clear Cotton effect was not confirmed in the Rac polymers. In particular, although the UV-vis and CD spectra of $\mathbf{1}(\mathbf{R})$ and $\mathbf{1}(\mathbf{S})$ were observed to be red-shifted as compared to those of the model compounds $\mathbf{4}(\mathbf{R})$ and $4(S)$, the Cotton effects of the two model compounds at around $220 \mathrm{~nm}$ were weak in both cases, while those for the polymers at around $230 \mathrm{~nm}$ were sufficiently larger. This result suggested the generation of some secondary structures in a polymer state (Figure 1).
On the other hand, although the UV-vis and CD spectra were observed to be red-shifted, the Cotton effects of the model compounds were very similar to those of polymers $\mathbf{2}(\mathbf{R}), \mathbf{2}(\mathbf{S})$ and $\mathbf{3}(\mathbf{R}), \mathbf{3}(\mathbf{S})$. In these cases, it was not clear whether the main-chain chirality was induced by the polymerization (Figure 2).

The CD intensity of $\mathbf{1}(\mathbf{R})$ was observed to have slight temperature dependence (Figure 3). For example, the CD intensity in $\mathbf{1}(\mathbf{R})$ gradually decreased with increasing temperature; therefore, some secondary structures were disordered at high temperature. ${ }^{12}$

Polyamines can be converted to water-soluble polymers with ammonium salts in the main chain by adding them to the appropriate acid. Polyamine 1(R) was dissolved in an acidic water solution (3:7 mixed solvent of $0.17 \mathrm{~N}$ hydrochloric acid and THF) at a concentration of $5 \times 10^{-4} \mathrm{M}$. From the CD spectrum, similar $\mathrm{CD}$ intensities and Cotton effects were observed in both the THF and acidic water solutions (Figure 3). Therefore, the optically active polyamine also might have some stable secondary structures in the acidic water solution.

\section{CONCLUSION}

In conclusion, a new optically active polyamine was easily prepared by the polycondensation of chiral 1-cyclohexylethylamine derivatives with $p$-xylylene dibromide in the presence of $\mathrm{K}_{2} \mathrm{CO}_{3}$. Although the detailed structures of the polymers have not yet been clarified, it is possible that they take on some helical structures induced by the introduction of a bulky chiral amine. In addition, the obtained polyamines have considerable potential for applications in the development of novel materials. Future works include the evaluation of the bulk properties of polymers, molecular recognition of chiral compounds, and the investigation of the ability of an additive to fold or unfold some proteins. ${ }^{13}$

Acknowledgment. We thank Dr. Takeshi Maeda (Kyushu University) for helpful discussion. This work was partially supported by the Industrial Technology Research \& Development Grant (04A23030) from NEDO of JAPAN. 


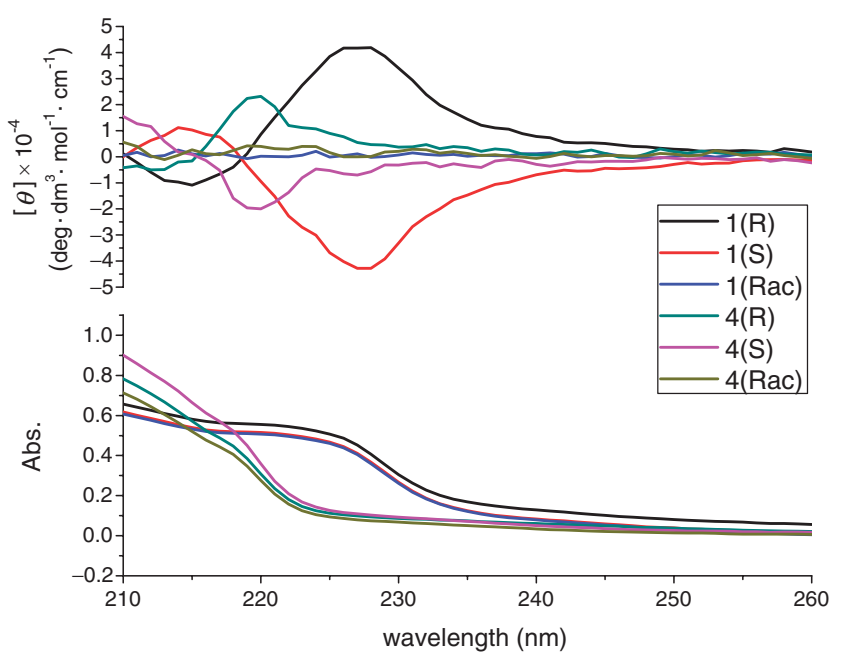

Figure 1. $C D$ and UV-vis spectra of polymer 1 and model compound 4 (THF, $20^{\circ} \mathrm{C}, 210-260 \mathrm{~nm}, \mathrm{c} 5 \times 10^{-4} \mathrm{M}$ for 1 , c $4 \times 10^{-4} \mathrm{M}$ for 4 ).

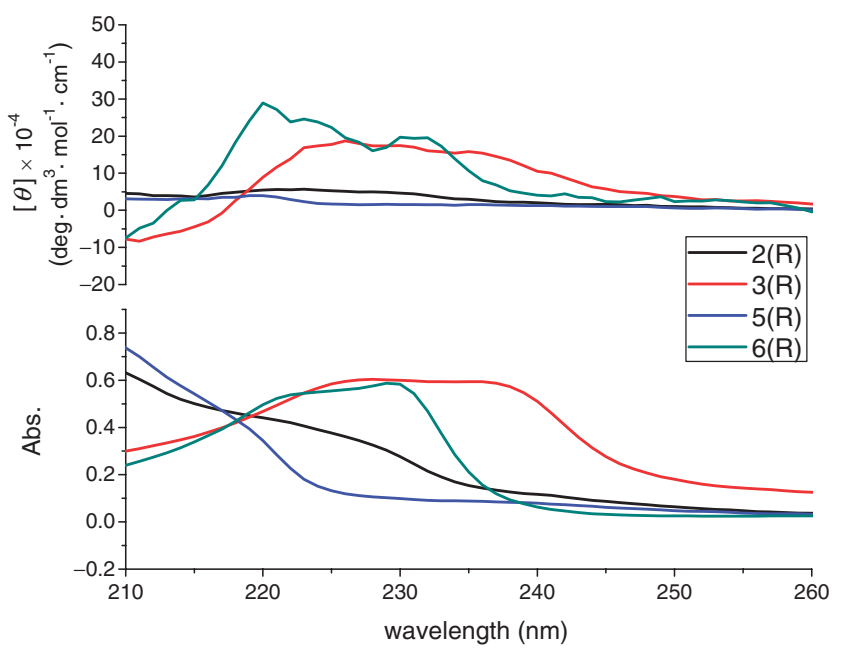

Figure 2. $C D$ and UV-vis spectra of polymer 2, 3 and model compound 5, 6 (THF, $20^{\circ} \mathrm{C}, 210-260 \mathrm{~nm}, \mathrm{c} 2.5 \times 10^{-4} \mathrm{M}$ for 2 and 5 , c $1 \times 10^{-4}$ $\mathrm{M}$ for 3 , c $3 \times 10^{-5} \mathrm{M}$ for 6 ).

Electronic Supporting Information Available: Spectral data of polymers and model compounds, Figures S1, S2, S3, S4, and S5. These materials are available via the Internet at http:// www.spsj.or.jp/c5/pj/pj.htm

Received: January 26, 2009 Accepted: February 21, 2009

Published: April 8, 2009

\section{REFERENCES}

1. a) Y. Okamoto and T. Nakano, Chem. Rev., 94, 349 (1994). b) T. Nakano and Y. Okamoto, Chem. Rev., 101, 4013 (2001). c) E. Yashima and K. Maeda, Macromolecules, 41, 3 (2008).

2. a) Y. Okamoto, S. Honda, I. Okamoto, H. Yuki, S. Murata, R. Noyori, and H. Takaya, J. Am. Chem. Soc., 103, 6971 (1981).

b) T. Ikai, C. Yamamoto, M. Kamigaito, and Y. Okamoto, Polym. J., 38, 91 (2006).

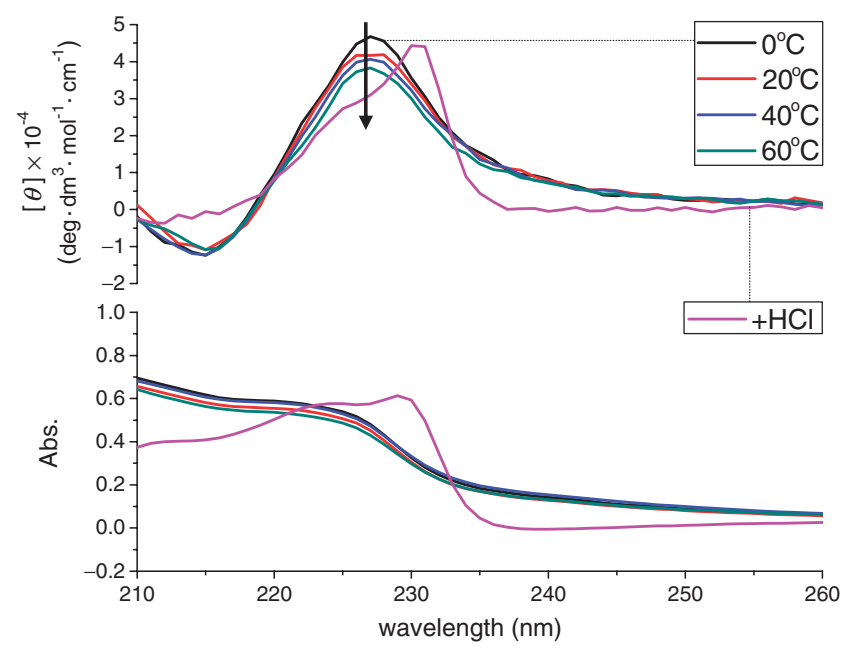

Figure 3. Temperature dependency (THF, $\left.20^{\circ} \mathrm{C}, 210-260 \mathrm{~nm}, 5 \times 10^{-4} \mathrm{M}\right)$ and additive effect of $\mathrm{HCl}\left(\mathrm{THF} / 0.17 \mathrm{~N} \mathrm{HCl}_{\mathrm{aq}}=3 / 7,20^{\circ} \mathrm{C}, 210\right.$ $260 \mathrm{~nm}, 5 \times 10^{-4} \mathrm{M}$ ) on CD spectra of polymer $\mathbf{1 ( R )}$.

3. a) T. Aoki and T. Kaneko, Polym. J., 37, 717 (2005). b) M. Teraguchi, K. Mottate, S. Y. Kim, T. Aoki, T. Kaneko, S. Hadano, and T. Masuda, Macromolecules, 38, 6367 (2005).

4. a) Y. Okamoto, K. Suzuki, K. Ohta, K. Hatada, and H. Yuki, J. Am. Chem. Soc., 101, 4763 (1979).

b) T. Nakano, A. Matsuda, M. Mori, and Y. Okamoto, Polym. J., 28, 330 (1996).

c) Y. K. Lee, N. Hisamitsu, K. Onimura, H. Tsutsumi, and T. Oishi, Polym. J., 34, 9 (2002).

5. a) N. Hoshikawa, Y. Hotta, and Y. Okamoto, J. Am. Chem. Soc., 125 , 12380 (2003).

b) Y. Amano and Y. Okamoto, Polym. J., 37, 629 (2005).

6. S. Lifson, C. E. Felder, and M. M. Green, Macromolecules, 25, 4142 (1992).

7. a) R. Nomura, J. Tabei, and T. Masuda, J. Am. Chem. Soc., 123, 8430 (2001).

b) K. Akagi, G. Piao, S. Kaneko, K. Sakamaki, and H. Shirakawa, Science, 282, 1683 (1998).

c) T. Aoki, K. Shinohara, and E. Oikawa, Chem. Lett., 22, 2009 (1993).

d) T. Aoki, T. Kaneko, N. Maruyama, A. Sumi, M. Takahashi, T. Sato, and M. Teraguchi, J. Am. Chem. Soc., 125, 6346 (2003).

e) T. Hasegawa, K. Maeda, H. Ishiguro, and E. Yashima, Polym. J., 38, 912 (2006).

f) T. Takata, F. Ishiwari, T. Sato, R. Seto, and Y. Koyama, Polym. J., 40, 846 (2008).

g) F. Sanda, T. Fujii, M. Shiotsuki, and T. Masuda, Polym. J., 40, 768 (2008).

h) Y. M. Hu, R. Y. Liu, F. Sanda, and T. Masuda, Polym. J., 40, 143 (2008).

i) Y. M. Hu, M. Shiotsuki, F. Sanda, and T. Masuda, Polym. J., 39, 968 (2007).

j) K. Itomi, S. Kobayashi, K. Morino, H. Iida, and E. Yashima, Polym. J., 41, 108 (2009).

8. a) M. Fujiki, J. Am. Chem. Soc., 116, 11976 (1994).

b) J. Watanabe, H. Kamee, and M. Fujiki, Polym. J., 33, 495 (2001)

9. a) T. Takata, Y. Furusho, K. Murakawa, T. Endo, H. Matsuoka, T. Hirasa, J. Matsuo, and M. Shishido, J. Am. Chem. Soc., 120, 4530 (1998).

b) R. Seto, T. Maeda, G. Konishi, and T. Takata, Polym. J., 39, 1351 (2007).

c) K. Maeyama, S. Maeda, H. Saito, and N. Yonezawa, Polym. J., 39, 342 (2007).

d) K. Maeyama, I. Hikiji, K. Ogura, A. Okamoto, K. Ogino, H. Saito, 
and N. Yonezawa, Polym. J., 37, 707 (2005).

e) K. Maeyama, K. Ogura, A. Okamoto, K. Ogino, H. Saito, and N. Yonezawa, Polym. J., 37, 736 (2005).

10. a) M. Inouye, M. Waki, and H. Abe, J. Am. Chem. Soc., 126, 2022 (2004).

b) M. Waki, H. Abe, and M. Inouye, Angew. Chem., Int. Ed., 46, 3059 (2007).
11. a) E. Yashima, S. Huang, T. Matsushima, and Y. Okamoto, Macromolecules, 28, 4184 (1995).

b) K. Maeda and Y. Okamoto, Polym. J., 30, 100 (1998).

12. H.-Z. Tang, M. Fujiki, and T. Sato, Macromolecules, 35, 6439 (2002).

13. a) M. Kudou, K. Shiraki, S. Fujiwara, T. Imanaka, and M. Takagi, Eur. J. Biochem., 270, 4547 (2003).

b) A. Hirano, H. Hamada, and K. Shiraki, Protein J., 27, 253 (2008). 